\title{
Perbandingan Penggunaan Platform Google Classrom Dan Grup Whatsapp Dalam Pembelajaran Online Selama Pandemi Covid-19
}

\author{
Endah Yuliani ${ }^{*}$, Romadhiyana Kisno Saputri ${ }^{2}$ \\ ${ }^{1}$ Universitas PGRI Adi Buana, ${ }^{2}$ Universitas Nahdlatul Ulama Sunan Giri \\ *endahyuliani07@gmail.com
}

\begin{abstract}
The impact of COVID-19 pandemic on the education system in Indonesia is all learning activities implemented in their respective homes through the available applications. Online learning is done through various platforms like google classroom and whatsapp group. The implementation of online learning needs to use a platform that is able to support the achievement of course objectives, for that, it is necessary to know which platform is able to support the achievement of course objectives so that learning outcomes are also good. This study aims to compare learning outcomes using the google classroom platform and whatsapp group and how effective these two platforms during the COVID-19 pandemic. This is a quasi-experimental study with a nonequivalent multiple-group pretest-posttest design. The population in this study were all 2nd semester students who had an online learning using Google Classroom and Whats App Group. The sample in this study amounted to 48 students who were divided into 2 groups according to treatment with the number of each group of 24 students. Student learning outcomes data were obtained from the pre-test results, from the Middle Semester Exam scores before online learning was carried out and the post-test scores, from the Final Semester Exam scores after online learning was carried out in the two treatment groups, the data were then processed using Microsoft Excell and SPSS 25 software. The results showed that the learning outcomes of the two classes were the same before being treated and the learning outcomes of the two classes were different after being treated or in other words the class using the google classroom platform was better than the class using the whatsapp group platform. Learning with google classroom platform more effective than learning with whatsapp group platform.
\end{abstract}

Keywords: google classroom; grup whatsapp; learning outcomes

\section{ABSTRAK}

Dampak dari adanya pandemi COVID-19 pada sistem pendidikan di Indonesia adalah seluruh kegiatan pembelajaran dilaksanakan di rumah masing-masing melalui aplikasi yang tersedia. Pembelajaran online dilakukan melalui berbagai platform seperti google classroom dan grup whatsapp. Pelaksanaan pembelajaran online perlu menggunakan platform yang mampu menunjang ketecapaian tujuan mata kuliah, untuk itu, perlu diketahui platform mana yang mampu menunjang ketercapaian tujuan mata kuliah sehingga hasil belajar juga baik. Penelitian ini bertujuan untuk membandingkan hasil belajar yang menggunakan platform google classroom dan grup whatsapp dan seberapa efektifnya kedua platform tersebut selama pandemi COVID-19. Jenis penelitian yang dilakukan pada penelitian ini adalah penelitian quasi experiment dengan desain pretest-postest nonequivalent multiple-group design. Populasi dalam penelitian ini adalah seluruh mahasiswa semester 2 yang mengikuti pembelajaran online dengan google classroom dan grup whatsapp. Sampel pada penelitian ini berjumlah 48 mahasiswa yang terbagi menjadi 2 kelompok sesuai perlakuan dengan jumlah masing-masing kelompok 24 mahasiswa. Data hasil belajar mahasiswa diperoleh dari hasil pre test, yaitu nilai Ujian Tengah Semester sebelum dilaksanakan pembelajaran online dan nilai post test, yaitu nilai Ujian Akhir Semester setelah dilaksanakan pembelajaran online pada kedua kelompok perlakuan, data kemudian diolah dengan menggunakan bantuan software Microsoft Excell dan SPSS 25 Hasil penelitian menunjukan bahwa hasil belajar kedua kelas sama sebelum diberi perlakuan dan hasil belajar kedua kelas berbeda setelah diberi perlakuan atau dengan kata lain kelas yang menggunakan platform google classroom lebih baik dari pada kelas yang menggunakan platform grup whatsapp. Pembelajaran dengan platform google classroom lebih efektif daripada dengan platform grup whatsapp.

Kata Kunci: google classroom; grup whatsapp; hasil belajar

Submitted Mar 10, 2021 | Revised Mar 21, 2021 | Accepted Mar 28, 2021

\section{Pendahuluan}

COVID-19 masuk ke Indonesia sejak awal bulan Maret 2020. Pemerintah Indonesia langsung menindak lanjuti kasus tersebut dengan melakukan social distancing selama 14 hari untuk meminimalisir penyebaran virus tersebut. Menteri pendidikan mengeluarkan Surat Edaran Nomor 3 Tahun 2020 
Tentang Pencegahan Corona Virus Disease (COVID-19) pada satuan pendidikan yang menyatakan bahwa meliburkan sekolah dan perguruan tinggi. Hal ini dilakukan untuk memutus mata rantai penyebaran COVID-19 (Pratiwi, 2020). Selama masa pandemi COVID-19 mengharuskan setiap satuan pendidikan melaksanakan proses pembelajaran daring, tidak hanya untuk mata kuliah teori, namun juga untuk mata kuliah praktik, termasuk (Al-Bari \& Saputri, 2020). Tidak semua pelajar, siswa dan mahasiswa terbiasa belajar melalui pembelajaran online. Masih banyak guru dan dosen yang belum mahir mengajar dengan menggunakan teknologi internet atau media sosial terutama di berbagai daerah (Purwanto et al., 2017). Penerapan pembelajaran online di SMK Negeri 1 Tambelangan masih membutuhkan sedikit peningkatan pada beberapa faktor antara lain kesiapan peserta didik dan faktor kesiapan infrastruktur (Jamal, 2020). Penelitian lain tentang kesiapan mahasiswa menggunakan pembelajaran online menunjukkan tiga dari empat indikator kesiapan mahasiswa dalam pelaksanaan pembelajaran online menunjukkan kategori siap dan 1 indikator dalam kategori tidak siap yaitu indikator yaitu sikap positif mahasiswa terhadap teknologi komputer dan internet (Setiaji \& Dinata, 2020). Penyebab mahasiswa kesulitan mengakses pembelajaran online antara lain kondisi jaringan yang tidak stabil atau tidak memadai, gadget/perangkat yang tidak kompatibel dengan aplikasi pembelajaran online dan kuota internet yang terbatas (Maulana \& Hamidi, 2020).

Aktivitas pembelajaran online yang sudah dilaksanakan selama kurang lebih 3 bulan ini dirasakan mahasiswa menjenuhkan dan membosankan, sehingga dihapkan para dosen lebih kreatif dan inovatif dalam memanfaatkan media yang digunakan agar proses pembelajaran lebih menyenangkan (Aswasulasikin, 2020). Pembelajaran online atau daring (dalam jaringan) dilakukan melalui berbagai aplikasi yang dapat menunjang proses pembelajaran mulai dari aplikasi tatap muka seperti zoom, google meet, dan platform media online lainnya seperti google classroom, whatsapp group, dan sebagainya. Aplikasi google classroom dipilih untuk membantu mahasiswa dan dosen sebagai pengajar melakukan perkuliahan secara online. Google classroom merupakan aplikasi berupa learning system management yang disediakan google dan bisa dihubungkan dengan email, sehingga mudah untuk diakses (Suhada et al., 2020). Pembelajaran online berbasis virtual class dengan google classroom menjadi lebih bermakna karena materi pembelajaran yang disediakan dirancang sedemikian rupa sehingga peserta didik lebih mudah memahaminya. Selain itu, materi bisa di ulang-ulang ketika ada materi yang kurang dipahami sehingga dapat meningkatkan hasil belajar peserta didik. Penggunaan google clasroom tidak perlu melakukan proses instalasi yang rumit sehingga dapat memfasilitasi pembelajaran online untuk peserta didik selama pandemi COVID-19 (Nurfalah, 2019). Kehadiran google classroom sebagai salah satu media pembelajaran diminati dan membuat pengalaman baru mahasiswa (Hapsari \& Pamungkas, 2019). Whatsapp merupakan platform pesan yang dapat digunakan dalam pembelajaran jarak jauh, dimana mahasiswa dikumpulkan disatu grup dan proses pembelajaran dilaksanakan secara pesan baik dengan tulisan, suara maupun gambar. Aplikasi ini digunakan oleh pendidik dikarenakan dikenal hemat kuota dan familiar dikalangan peserta didik, karena rata-rata semua nomor yang dimiliki sudah terkoneksi dengan aplikasi ini (Kusuma \& Hamidah, 2020). Grup whatsapp merupakan sebuah layanan grup diskusi yang mampu menampung hingga 256 peserta. Para anggotanya dapat saling berbagi diskusi dan informasi secara online melalui ruang virtual tersebut. Grup whatsapp memiliki manfaat pedagogis, sosial, dan teknologi. Aplikasi ini memberikan dukungan dalam pelaksanaan pembelajaran secara online. Grup whatsapp memungkinkan para penggunanya untuk menyampaikan pengumuman tertentu, berbagi ide dan sumber pembelajaran, serta mendukung terjadinya diskusi secara online. Grup whatsapp tersebut saat ini dijadikan wadah diskusi untuk memecahkan berbagai masalah, pertanyaan dan sesuatu yang penting yang harus disampaikan terhadap orang-orang yang tergabung di dalamnya. Diskusi melalui grup whatsapp ini sangat membantu penggunanya untuk berkomunikasi dalam online (Jumiatmoko, 2016).

Hasil belajar adalah suatu penilaian akhir dari proses dan pengenalan yang telah dilakukan berulang-ulang. Serta akan tersimpan dalam jangka waktu lama atau bahkan tidak akan hilang selamalamanya karena hasil belajar turut serta dalam membentuk pribadi individu yang selalu ingin mencapai 
hasil yang lebih baik lagi sehingga akan mengubah cara berpikir serta menghasilkan perilaku kerja yang lebih baik. Faktor-faktor yang mempengaruhi hasil belajar antara lain metode mengajar, kurikulum, relasi pendidik dan peserta didik, relasi peserta didik dan peserta didik dan disiplin perguruan tinggi (Sulastri et al., 2015). Terdapat pengaruh yang signifikan dari persepsi media pembelajaran terhadap hasil belajar peserta didik. Media pembelajaran adalah segala jenis sarana pengajaran yang digunakan sebagai perantara dalam proses belajar mengajar untuk meningkatkan efektivitas dan efisiensi pencapaian tujuan pendidikan. Media berhasil membawa pesan belajar apabila kemudian terjadi perubahan tingkah laku atau sikap belajar pada diri peserta didik. Faktor-faktor yang mempengaruhi pemilihan media pembelajaran antara lain objektivitas, keefektifan, dan efesiensi penggunaan media pembelajaran. Pemilihan media pembelajaran berdasarkan kebutuhan nyata yang telah direncanakan, khususnya yang berkenaan dengan tujuan yang dirumuskan dalam bahan ajar yang hendak disampaikan. Pemilihan media pembelajaran yang benar-benar disesuaikan dengan karakteristik umum peserta didik akan memudahkan peserta didik untuk memahami materi pelajaran yang akan disajikan pendidik (Mardhiah \& Ali Akbar, 2018). Tujuan adanya media yang baik adalah pada bagian perubahan sikap peserta didik dan tidak secara langsung berpengaruh terhadap prestasi belajar (Nuryanti, 2004). Gangguan dalam proses belajar langsung antara peserta didik dan pendidik berdampak pada psikologis anak didik dan menurunnya kualitas keterampilan murid (Syah, 2020). Untuk itu, perlu dilakukan evaluasi terhadap pembelajaran online sebagai bahan dasar perbaikan untuk selanjutnya. Berdasarkan dari uraian di atas, perlu adanya penelitian tentang perbandingan penggunaan platform whatsapp group dan google classrom dalam pembelajaran online pada masa pandemik COVID-19. Penelitian ini bertujuan untuk mengetahui membandingkan hasil belajar yang menggunakan platform google classroom dan grup whatsapp dan seberapa efektifnya kedua platform tersebut selama pandemi COVID-19.

\section{Metode Penelitian}

Jenis penelitian yang dilakukan adalah penelitian quasi experiment untuk melihat akibat dari suatu perlakuan dengan membandingkan hasil belajar dua kelompok kelas. Adapun desain yang digunakan adalah pretest-postest nonequivalent multiple-group design. Populasi dalam penelitian ini adalah seluruh mahasiswa semester 2 yang mengikuti pembelajaran online dengan google classroom dan grup whatsapp. Sampel ada penelitian ini berjumlah 48 mahasiswa yang terbagi menjadi 2 kelompok sesuai perlakuan dengan jumlah masing-masing kelompok 24 mahasiswa. Data hasil belajar mahasiswa diperoleh dari hasil pre test, yaitu nilai Ujian Tengah Semester sebelum dilaksanakan pembelajaran online dan nilai post test, yaitu nilai Ujian Akhir Semester setelah dilaksanakan pembelajaran online pada kedua kelompok perlakuan, data kemudian diolah dengan menggunakan bantuan software Microsoft Excell dan SPSS 25 dengan langkah sebagai berikut:

a. Menghitung rerata dan standar deviasi.

b. Menguji normalitas data sampel.

c. Uji Perbedaan Rata-Rata.

\section{Hasil dan Pembahasan}

Hasil belajar mahasiswa diperoleh dari hasil pre-post test yang dilaksanakan saat materi diberikan pada dua kelas. Kelas $\mathrm{R}$ adalah kelas yang menggunakan platform google classroom dalam pembelajaran dan kelas $\mathrm{S}$ adalah kelas yang menggunakan grup whatsapp. Penamaan kelas $\mathrm{R}$ dan $\mathrm{S}$ secara random agar tidak menimbulkan persepsi kelas yang lebih bagus. Hasil belajar mahasiswa disajikan pada tabel 1. 
Tabel 1. Hasil Belajar Mahasiswa

\begin{tabular}{lcccc}
\hline Hasil Belajar & \multicolumn{2}{c}{ Kelas R } & \multicolumn{2}{c}{ Kelas S } \\
Mahasiswa & Rerata & SD & Rerata & SD \\
\hline Pre-test & 70,46 & 7,41 & 81,66 & 15,76 \\
Post-test & 75,29 & 8,01 & 77,03 & 11,67 \\
\hline
\end{tabular}

Berdasarkan tabel 1, secara deskriptif, pre-test hasil belajar mahasiswa pada kelas yang menggunakan platform google classroom (Kelas S) lebih baik dibandingkan yang menggunakan platform Grup Whatsapp. Hal ini sejalan dengan penelitian yang dilakukan tentang pembelajaran daring berbasis google classroom dimana disimpulkan bahwa penggunaan aplikasi google classroom dalam pembelajaran daring pada masa wabah COVID-19 sudah cukup baik dan efektif, 62,63\% mahasiswa menyatakan setuju dalam pemahaman materi pembelajaran dengan menggunakan google classroom, 60,42\% mahasiswa menyatakan setuju dalam keefektifan penggunaan aplikasi google classroom, dan 46,74\% mahasiswa menyatakan setuju dalam penggunaan aplikasi google classroom dalam pembelajaran (Suhada et al., 2020). Penelitian lain tentang keefektifan penggunaan google classroom sebagai media pembelajaran juga menunjukkan aspek evaluasi pelaksanaan pembelajaran google classroom menuunjukkan kategori cukup efektif dengan kecenderungan sebesar 69,01\%. Faktor pendukung pelaksanaan google classroom yaitu kesiapan SDM untuk meningkatkan pem-belajaran elearning, fasilitas software untuk mengembangkan media pembelajaran, fasilitas sarana internet, dan kebutuhan pelaksanaan media pembelajaran untuk meningkatkan dan menambah aktivitas pembelajaran di kelas. Faktor penghambat pelaksanaan pembelajaran google classroom antara lain kurangnya motivasi dalam mengembangkan pembelajaran google classroom dikarenakan tersedianya fasilitas belajar yang lain di kelas (Sabran \& Sabara, 2019).

Proses belajar yang kurang maksimal dapat menyebabkan hasil belajar yang kurang maksimal. performa google classroom dapat menunjang pembelajaran karena dengan google classroom ini mahasiswa dimudahkan untuk menyimpan dokumen seperti materi maupun tugas penting yang dikirim lewat google classroom, sehingga jika mahasiswa belum sempat untuk mencetak dokumen yang diperlukan, mereka dapat mengakses terlebih dahulu melalui classroomnya masing-masing. Selain itu mahasiswa juga dimudahkan untuk memperoleh pengumuman yang diberikan oleh dosen secara cepat (real time) sehingga menjadi efektif dan efisien dari segi waktu. Mahasiswa juga dapat melihat nilainya secara langsung setelah dikoreksi. Hal inilah yang membuat mahasiswa termotivasi dalam pembelajaran karena tugas yang diberikan bisa tiap saat diubah jika masih ada yang kurang, terlebih lagi mereka dapat mengetahui kapan deadline dari tugas yang diberikan. Selain itu, mereka tidak perlu menggunakan kertas untuk mengumpulkan tugas-tugasnya. Sehingga dapat disimpulkan bahwa penggunaan google classroom dapat memotivasi mahasiswa dalam belajar (Widyantara, 2020). Pada penelitian ini, grup whatsapp tidak memiliki fitur sebaik google classroom. Fitur-fitur pada google classroom yang dirasakan memiliki banyak manfaat bagi responden antara lain tugas, penilaian dan komunikasi. Dalam fitur komunikasi, dimungkinkan terjadinya komunikasi dua arah antara dosen dan mahasiswa, selain itu, penyimpanan media pada platform google classroom lebih besar kapasitasnya dan lebih mudah diakses. Dibandingkan dengan google classroom keterbatasan grup whatsapp dalam pembelajaran antara lain pengiriman dan penyimpanan file yang terbatas ukurannya serta tidak adanya fitur tugas dan penilaian. Hal ini menyebabkan grup whatsapp belum mampu meningkatkan motivasi belajar mahasiswa yang akhirnya menyebabkan hasil belajar mahasiswa yang menggunakan platform google clasroom lebih baik dibandingkan menggunakan grup whatsapp.

Untuk menjawab pertanyaan penelitian maka dilakukan uji statistik dengan menggunakan uji perbedaan rerata. Rekapitulasi hasil uji perbedaan disajikan pada tabel 2. Sebelumnya dilakukan uji normalitas sebaran data hasil belajar mahasiswa, secara keseluruhan diperoleh bahwa data berdistribusi normal dan homogen. 
Tabel 2. Rekapitulasi Hasil Uji Perbedaan

\begin{tabular}{lll}
\hline Hasil Belajar Mahasiswa & Sig. & Interprestasi \\
\hline Pre-test & 0,284 & $\begin{array}{l}\text { Tidak terdapat perbedaan hasil belajar awal } \\
\text { sebelum perlakuan pada kelas R dan kelas S pada } \\
\text { taraf signifikansi } 5 \%\end{array}$ \\
Post-test & 0,030 & $\begin{array}{l}\text { Hasil belajar mahasiswa kelas eksperimen S lebih } \\
\text { baik daripada kelas R pada taraf signifikansi } 5 \%\end{array}$ \\
\hline
\end{tabular}

Berdasarkan tabel 2, menunjukan bahwa signifikansi nilai pre-test $>0,05$ yang artinya tidak terdapat perbedaan hasil belajar awal sebelum perlakuan pada kelas R dan kelas $S$ pada taraf signifikansi $5 \%$. Hal ini menjelaskan bahwa hasil postest tidak dipengaruhi oleh kemampuan awal mahasiswa. Selanjutnya signifikansi nilai post-test menunjukkan nilai $<0,05$ yang artinya terdapat perbedaan yang signifikan hasil belajar post-test kedua kelas atau hasil belajar kelas dengan google classroom lebih baik dari kelas dengan grup whatsapp. Hasil ini sejalan dengan penelitian yang dilakukan oleh Kusuma \& Hamidah (2020) yang menunjukkan platform grup whatsapp kurang efektif dibandingkan platform komunikasi dua arah pada pembelajaran jarak jauh pada masa pandemik COVID-19. Penggunaan platform grup whatsapp masih menjadi pilihan beberapa responden karena kemudahan akses dan adanya kemungkinan komunikasi dua arah dengan menggunakan fitur videocall, namun pada kenyatannya, pada penelitian ini, grup whatsapp kurang efektif karena materi yang dibagikan melalui grup whatsapp terbatas, baik dari segi ukuran file maupun jenis file materi.

Pembelajaran daring yang dilakukan selama pandemi Covid-19 sangat dimudahkan dengan adanya berbagai pilihan media pembelajaran. Pemilihan media pembelajaran yang akan digunakan pada umumnya berdasarkan kesepakatan bersama antara dosen dan mahasiswa. Dari berbagai pilihan tersebut, pola komunikasi yang terbentuk dapat di kelompokkan menjadi tiga macam, yaitu komunikasi satu arah, komunikasi semi dua arah, dan komunikasi dua arah. Google classroom dan grup whatsapp merupakan salah satu jenis model komunikasi semi dua arah (Zhafira et al., 2020). Pada penelitian ini, penggunaan google classroom menunjukkan hasil belajar yang lebih baik dibandingkan dengan grup whatsapp karena saat menggunakan google classroom dosen juga membagikan link untuk bergabung secara live di platform youtube sehingga komunikasi menjadi komunikasi dua arah. Adanya komunikasi dua arah ini meningkatkan pemahaman peserta didik tentang materi yang diberikan dosen sehingga hasil belajar juga lebih baik.

\section{Kesimpulan}

Berdasarkan hasil penelitian, dapat ditarik kesimpulan bahwa hasil belajar pada kelas yang menggunakan platform google classroom lebih baik daripada kelas yang menggunakan platform grup whatsapp. Selanjutnya, diketahui bahwa pembelajaran dengan platform google classroom lebih efektif dari pada dengan platform grup whatsapp.

\section{Daftar Pustaka}

Al-Bari, A., \& Saputri, R. K. (2020). Persepsi Mahasiswa Terhadap Praktikum Daring Mata Kuliah Kimia Analisis. Jurnal Educatio FKIP UNMA, 6(2), 676-683. https://doi.org/10.31949/educatio.v6i2.723

Aswasulasikin. (2020). Persepsi Mahasiswa Terhadap Kuliah Daring dimasa Pandemi Corona Virus Disease (COVID-19). SALAM Jumal Sosial Dan Budaya Syar'i, 7(10), 7-12.

Hapsari, S. A., \& Pamungkas, H. (2019). Pemanfaatan Google Classroom Sebagai Media Pembelajaran Online Di Universitas Dian Nuswantoro. WACANA: Jumal Ilmiah Ilmu Komunikasi, 18(2). https://doi.org/10.32509/wacana.v18i2.924

Jamal, S. (2020). Analasis Kesiapan Pembelajaran E-learning Saat Pandemi Covid-19 Di Smk Negeri 1 Tambelangan. Jurnal Nalar Pendidikan, 8(1), 16-22. 
Jumiatmoko, M. (2016). Whatsapp Messenger Dalam Tinjauan Manfaat Dan Adab. Wahana Akademika: Jurnal Studi Islam Dan Sosial, 3(1), 51. https://doi.org/10.21580/wa.v3i1.872

Kusuma, J. W., \& Hamidah, H. (2020). Perbandingan Hasil Belajar Matematika Dengan Penggunaan Platform Whatsapp Group Dan Webinar Zoom Dalam Pembelajaran Jarak Jauh Pada Masa Pandemik Covid 19. JIPMat, 5(1). https://doi.org/10.26877/jipmat.v5i1.5942

Mardhiah, A., \& Ali Akbar, S. (2018). Efektivitas Media Pembelajaran Terhadap Hasil Belajar Kimia Siswa Sma Negeri 16 Banda Aceh. Lantanida Journal, 6(1), 49. https://doi.org/10.22373/lj.v6i1.3173

Maulana, H. A., \& Hamidi, M. (2020). Persepsi Mahasiswa terhadap Pembelajaran Daring pada Mata Kuliah Praktik di Pendidikan Vokasi. Equilibrium: Jumal Pendidikan, VIII(2), 224-231.

Nurfalah, E. (2019). Optimalisasi E-Learning berbasis Virtual Class dengan Google Classroom sebagai Media Pembelajaran Fisika. Physics Education Research Journal, 1(1), 46. https://doi.org/10.21580/perj.2019.1.1.3977

Nuryanti, L. (2004). Model Pembelajaran E-Learning Melalui Homepage Sebagai Media Pembelajaran Sehingga Diharapkan Dapat Meningkatkan Minat Dan Kreativitas Siswa. Abmas, 1(1), 1-6.

Pratiwi, E. W. (2020). Dampak Covid-19 Terhadap Kegiatan Pembelajaran Online Di Sebuah Perguruan Tinggi Kristen Di Indonesia. Perspektif Ilmu Pendidikan, 34(1), 1-8. https://doi.org/http://doi.org/10.21009/PIP.341.1

Purwanto, A., Pramono, R., Asbari, M., Santoso, P. B., Wijayanti, L. M., Hyun, C. C., \& Putri, R. S. (2017). Studi Eksploratif Dampak Pandemi COVID-19 Terbadap Proses Pembelajaran Online di Sekolah Dasar. 2(1), 165-170.

Sabran, \& Sabara, E. (2019). Keefektifan Google Classroom sebagai media pembelajaran. PROSIDING Seminar Nasional Lembaga Penelitian Universitas Negeri Makasar, 122-125. https://webcache.googleusercontent.com/search?q=cache:SS_jKM_r2TAJ:https://ojs.unm.ac.id /semnaslemlit/article/download $/ 8256 / 4767+\& \mathrm{~cd}=2 \& \mathrm{hl}=\mathrm{id} \& \mathrm{ct}=\mathrm{clnk} \& \mathrm{gl}=\mathrm{id}$

Setiaji, B., \& Dinata, P. A. C. (2020). Analisis kesiapan mahasiswa jurusan pendidikan fisika menggunakan e-learning dalam situasi pandemi Covid-19. Jurnal Inovasi Pendidikan IPA, 6(1), 5970. https://doi.org/10.21831/jipi.v6i1.31562

Suhada, I., Kurniati, T., Pramadi, A., Listiawati, M., Biologi, P. P., Gunung, S., \& Bandung, D. (2020). Pembelajaran Daring Berbasis Google Classroom Mahasiswa Pendidikan Biologi Pada Masa Wabah Covid-19. Digilib.Uinsgd.Ac.Id, 2019, 1-9. http://digilib.uinsgd.ac.id/30584/

Sulastri, Imran, \& Firmansyah, A. (2015). Meningkatkan Hasil Belajar Siswa Melalui Strategi Pembelajaran Berbasis Masalah Pada Mata Pelajaran IPS Di Kelas V SDN 2 Limbo mMakmur Kecamatan Bumi Raya. Jurnal Kreatif Tadulako Online, 3(1), 90-103.

Syah, R. H. (2020). Dampak Covid-19 pada Pendidikan di Indonesia: Sekolah, Keterampilan, dan Proses Pembelajaran. SALAM: Jurnal Sosial Dan Budaya Syar-I, 7(5). https://doi.org/10.15408/sjsbs.v7i5.15314

Widyantara, V. T. (2020). Konsep, penggunaan, perbandingan, kelebiban dan kekurangan serta implikasi google classroom sebagai media pembelajaran jarak jauh. May. https://www.researchgate.net/publication/341232720_Konsep_Penggunaan_Perbandingan_Kel ebihan_Dan_Kekurangan_Serta_Implikasi_Google_Classroom_Sebagai_Media_Pembelajaran_Ja rak_Jauh

Zhafira, N. H., Ertika, Y., \& Chairiyaton. (2020). Daring Sebagai Sarana Pembelajaran Selama Masa Karantina Covid-19. Jurnal Bisnis Dan Kajian Strategi Manajemen, 4(1), 37-45. https://doi.org/https://doi.org/10.35308/jbkan.v4i1.1981 